

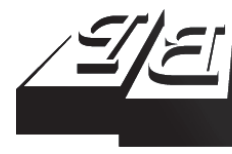

BUSINESS PERSPECTIVES

(O)

LLC "CPC "Business Perspectives" Hryhorii Skovoroda lane, 10, Sumy, 40022, Ukraine www.businessperspectives.org

Received on: $7^{\text {th }}$ of December, 2020 Accepted on: $28^{\text {th }}$ of May, 2021 Published on: $15^{\text {th }}$ of June, 2021

๑) Theresia Anita Christiani, 2021

Theresia Anita Christiani, PhD, Lecturer, Faculty of Law, Universitas Atma Jaya Yogyakarta, Indonesia.

\section{PROPOSED CHANGES TO THE BANK INDONESIA LAW AS A SOLUTION TO THE IMPACT OF THE COVID-19 SPREAD ON BANKING IN INDONESIA}

\begin{abstract}
Every amendment to the Bank Indonesia Law is caused by a situation that requires changes to the Law regulating the Central Bank in Indonesia as a solution. The spread of COVID-19 in Indonesia has also led to proposals to amend the Bank Indonesia Law. The purpose of the study is to find answers to the relevance of the proposed Amendment to Bank Indonesia Law to address the spread of COVID-19 to banking institutions in Indonesia. This type of research methods is normative legal research. In normative legal analysis, secondary data are used, consisting of primary and secondary legal materials. They are obtained from applicable regulations in Indonesia. The study results show that every change is always based on events that prove the weak implementation of existing rules with a regulatory and conceptual approach. The spread of COVID-19 is a situation, that has no practical basis and requires amendments to the Bank Indonesia Law as an alternative solution. Also, the proposed amendments are not yet relevant to address the impact of COVID-19 on banks because they have not yet realized and achieved the legal goals of providing benefits to the community.
\end{abstract}

$\begin{array}{ll}\text { Keywords } & \begin{array}{l}\text { alternative, change, problems, regulation, qualitative, } \\ \text { weak }\end{array}\end{array}$

JEL Classification K12, K22, O24

\section{INTRODUCTION}

The spread of COVID-19 has led the Indonesian Government to issue Law No. 2 of 2020 Concerning Law No. 2 of 2020 Stipulation of Government Regulation in Lieu of Law No. 1 of 2020 concerning State Financial Policy and Financial System Stability for Handling the Corona Virus Disease 2019 (Covid-19) Pandemic and/or In Facing Threats That Endanger the National Economy and/or Financial System Stability Becomes Law. Law No. 2 of 2020 provides a basis for the Government, Financial Services Authority, Bank Indonesia and related parties to overcome the impact of the spread of COVID-9 on Indonesia's economy. Based on Law No. 2 of 2020, a proposal was made to amend the Bank Indonesia Law at a hearing with the Legislative Body of the House of Representatives of the Republic of Indonesia in the current economic situation in Indonesia. The proposed amendments are the banking supervision function from the Financial Services Authority to Bank Indonesia, changes in the concept of Bank Indonesia independence, changes in the Formulation of Bank Indonesia's Goals, and the Proposal to Establish a Monetary Board. One of the significant issues for the Amendment of the Bank Indonesia Law that has emerged is to return bank supervision to Bank Indonesia. Based on Law No. 21 of 2011, micro-prudential regulation and supervision have been transferred to Financial Service Authority 
from Bank Indonesia. Returning micro-prudential regulation and supervision from the Financial Services Authority to Bank Indonesia as one of the proposed amendments to the Bank Indonesia Law and other proposed amendments is an urgent legal issue for discussion, due to, inter alia, the transfer of micro-prudential regulatory and supervisory duties from Bank Indonesia to the Financial Services Authority from a period and practice that had just occurred. Amending the Law is not only a legal but a political process. Therefore, the legal problem is formulated: Are the proposed amendments to the Bank Indonesia Law relevant as a solution to the impact of the spread of COVID-19 on banking institutions in Indonesia? The purpose of the study to find answers to the question of whether the proposed amendments to the Bank Indonesia Law are relevant as a solution to the impact of the spread of COVID-19 on banking institutions in Indonesia.

\section{LITERATURE REVIEW}

Law serves as a tool for social engineering, it is at the forefront of societal development. The function of Law as a social engineering tool was introduced by a thinker from the Sociological Jurisprudence school (Stone, 1966). As Roscoe Pound stated, there is a relevance of the function of Law. There is a relationship between legal norms and their function in controlling community activities (Barry, 1989). Community activity in question is an economic activity that requires the presence of Law (Tholl et al., 2020). Likewise, economic activities requiring banking institutions require a company to have a law guaranteeing the fulfillment of certainty of legal protection (Riles, 2021). A transparent and healthy banking institution is needed to develop the economic sector. Natural law theory can be used most in answering the real purpose of the Law itself. With regard to the meaning of Law, one can discuss the development of thoughts about the Law from the Greek era to the present. Aristotle was the first thinker to give his views on the purpose of Law. He said that humans are social beings, or the term given is the Zoon Politocoon. Aristotle said that the purpose of Law is to achieve a better life. He also distinguished between positive Law and Natural Law. Thomas Aquinas argues that the Law has a duty that lies in the heart (Mokriski, 2020). The legal objective is the legal objective put forward by Jeremy Bentham. Jeremy Bentham argues that something is considered acceptable or not measured by the consequences of that action. Jeremy Bentham is a thinker whose teachings are known as Utilitarianism (Cello, 2021). According to Bentham, the utility principle is a principle that approves or rejects any action that increases or decreases the party's happiness affected by the move. Approving and reject- ing the activity is seen from whether it is good or not (Niesen, 2019). In this case, the Government must increase the happiness that the community will enjoy. The best-known phrase from Bentham is "The greatest happiness for the greatest numbers." The purpose of Law is to achieve happiness for the majority of people. Utilitarianism theory is associated with legislators or legislators, and laws are a concrete form of Law. Legislators or legislators must try to make the Law bring happiness to the community. Jeremy Bentham's concept of utilitarianism is the basis for the philosophy of law formation used by Alanah Josey (2019) and EkeløveSlydal (2018) in their research. The purpose of seeking profit is used for the business's continuity and the company and benefits many people. If this is not the case, it can return the State's duty to regulate the purpose of seeking profit according to its nature.

Amendments to the Bank Indonesia Law are efforts made by the Government to achieve legal objectives in regulating economic activities and providing protection and benefits as, in essence, Jeremy Bentham said. Roscoe Pound's opinion that the Law is a tool for social engineering is used as a basis for analyzing whether the proposed amendments to the Bank Indonesia Law can realize the legal function of bringing about change in society. Meanwhile, the opinion of Jeremy Bentham that the purpose of Law is to provide benefits and happiness to the community is used in analyzing whether the proposed amendments to the Bank Indonesia Law will benefit the community. Based on those conceptual understanding, the basis for Bank Indonesia's formation as the Central Bank is mandated in the 1945 Constitution as the supreme Constitution in Indonesia, associated with a Central Bank in 
Indonesia as stated in Article $23 \mathrm{D}$ of the 1945 Constitution. This article confirms that "the State has a Central Bank whose composition, Law regulates authority, responsibility, and independence." The Central Bank's independence can be seen from three criteria: First, the Governor's appointment must be approved by the Parliament. Thus, the Central Bank's legal independence is measured by the Governor's position with the Parliament's approval. Second, the Central Bank's issue of accountability is responsible to Parliament, not to the President. Third, in determining monetary policy, an independent central bank has the power to decide monetary policy (Azikin, 2015; Cottarelli, 1994). Regulations in Indonesia have regulated the position of independence according to the three criteria. Some studies measure the Central Bank's independence from the inflation rate, the independence from the high and low inflation rates (Ferr'e \& Manzano, 2020). Concerning the independence of the Central Bank, Abdulkader Alquer conducted research related to the effect of the inflation target concerning the level of Central Bank's independence and transparency in determining monetary policy (Abdelkader, 2018). Bank Indonesia's position as an independent Central Bank has also experienced developments in existing regulations. The mandate of the Indonesian Constitution could only be realized in the 1999 Bank Indonesia Law. The provision of independence in the Bank Indonesia Law was due to a situation of monetary crisis that forced the regulation of the independence of Bank Indonesia as the Central Bank. Regulatory renewal is a form of reform in dealing with banking problems, stated by James R. Bath (Barth et al., 2004). The meaning of independence of Bank Indonesia has also undergone changes and developments from one regulation to the next. The meaning of independence changed before and after the Financial Services Authority Act was also changed with various new regulations related to the Central Bank. Law as a social engineering tool is manifested by the issuance of several regulations facing problems that can arise in the future. Also, at this time, the spread of the coronavirus caused the Indonesian Government to issue Law No. 2 of 2020 Concerning the Stipulation of Government Regulations in place of Law No. 1 of 2020. That Law on State Financial Policy and Financial System Stability for Handling the Corona Virus Disease 2019
Pandemic (COVID-19) and the Context of Facing Threats That Endanger the Economic and Financial System Stability enters into Law. That Law Number 2 of 2020 provides a basis for the Government, Financial Services Authority, Bank Indonesia, and related parties to take steps to overcome the impact of the spread of the COVID-19 pandemic on banks and the economy. This law issuance demonstrates the legal function's implementation as a social engineering tool as mandated by Roscoe Pound (Pound, 1940). Previous research uses the legal concept of legal function conducted by Mgr Alexander (Szpojankowski, 2019). The concept of legal functions as a tool for social engineering is also used in other legal research by Jedidiah (Kroncke, 2012) and Wirawan and Saputra (2020). The objective of the Central Bank is to keep currency exchange rates stable. Many factors influence the implementation of these tasks. The Governor's factor can be a determining factor for a Central Bank's competence, such as the results of research from Ozili (2020). Although Yessy Andriani and Prasanna Gai's analysis states that the Central Bank's independence will positively affect the inflation target, the Governor's change does not show any significance with the inflation target in Indonesia (Andriani \& Gai, 2013). Changing a law must have a background and urgency. Likewise, the proposed amendment to the Bank Indonesia Law is an effort so that the Law can become an instrument that helps the State in achieving happiness for the community. Several arguments are strong enough for the Bank Indonesia Law to be amended immediately. Since Law on Bank Indonesia in 1999 has been issued, there have been dynamics in developing other laws that have influenced the Bank Indonesia Law's provisions. These laws are the Financial Services Authority Law, the Currency Law, and the Law of Prevention and Management of Financial System Crisis. The last one is related to the existence of Law No. 2 of 2020. It is based on the principle of lex posterior derogat legi priori (Sudikno Mertokusumo, 2016), which implies that the new Law will defeat the old Law. The enactment of the Financial Services Authority Act in Indonesia has juridical consequences for Bank Indonesia's duties. The juridical consequence was that The FSA law transferred the supervisory responsibilities and even banking institutions' regulations to the Financial Services Authority. Bank 
Indonesia still has the task and authority to regulate and supervise the macroprudential sector. This is stipulated in Article 55, paragraph 2 of the Financial Services Authority Law, elucidation of article 7 in conjunction with article 40 of the Financial Services Authority Law). In detail, it can be stated that apart from the Financial Services Authority Law, there were juridical factors that led to changes to the Bank Indonesia Law. These juridical factors include the issuance of Law No. 9 of 2016 on the Prevention and Management of Financial System Crises, the Currency Law, and the existence of Law No. 2 of 2020. The last Law is a law formed in an economic situation affected by the spread of COVID-19. The Bank Indonesia Law must adapt to the changes in the world of rules and regulations in Indonesia, which have caused several laws and regulations in the Bank Indonesia Law to become irrelevant in accordance with the legal function as a social engineering tool. Central banking thinking development requires adjustments to the Central Bank's objectives to achieve and maintain the rupiah value's stability. Based on this, the adjustment of the Central Bank's duties will support the role of the Central Bank to promote the achievement of objectives. Indonesia's economy and financial system, integrated with the global economic system, demand Bank Indonesia's participation in creating financial system stability (Gaganis et al., 2021). The concept of the function of Law as a tool for social engineering has become the basis of arguments for the urgency of changing Bank Indonesia. The purpose of Law for the benefit of most society will be also used as the basis of conceptual framework and theory. There is a connection between the origin of argumentation with one another. The point is that the basis for this argument calls for resolution in the form of Amendments to the Bank Indonesia Law. The concept of the legal function and legal objectives will be used as a basis for analysis in discussing whether the proposed amendments to the Bank Indonesia Law are the answer to banking problems in overcoming the impact of the COVID-19 pandemic. The proposed amendments to the Bank Indonesia Law realize the legal function as a social engineering tool (Roscoe Pound) if the amendments can substantially change Bank Indonesia in terms of position, duties, goals and institutions for the better. If this change for the better occurs, then the legal objective to benefit the community, as stated by Jeremy Bentham, will be achieved. The regulatory approach is used as this study uses various regulations related to the proposed amendment to the Bank Indonesia Law. The conceptual approach is used because several banking legal concepts are used to analyze the problem of proposed changes to the Bank Indonesia law in terms of its relevance as a solution to the impact of the spread of COVID-19 on banking institutions in Indonesia.

\section{RESEARCH METHODS}

The type of research is normative legal research. The normative legal analysis uses secondary data consisting of primary and secondary legal materials (Suhartini et al., 2019). They are sourced from applicable regulations in Indonesia. Hierarchical regulation will become a source of Law. The Law adheres to the Civil Law System. The primary legal materials will complement secondary legal materials consisting of expert opinions and related articles from journals and dictionaries. Data analysis begins with collecting data, separating the data according to its relevance to the problem, then describing and analyzing the data using qualitative techniques. The data used is secondary data. Qualitative data are used to support qualitative analysis (Suradiyanto, 2019). The approach used is the statutory approach (Sudika, 2021) and conceptual approach (Sudiarawan et al., 2020). The regulatory approach is used to study existing legal problems by reviewing the Bank Indonesia Law and other related laws. The conceptual approach is used to analyze legal issues using legal function and legal objectives. Also, deductive conclusion techniques are used.

\section{RESULTS AND DISCUSSION}

There are at least 12 (twelve) proposals for amendments to articles and two recommendations for deletions proposed in the amendments to the Bank Indonesia Law. The submitted amended articles include Article 4, 7, 10, 11, 34, 43, 55, 56, 62, and 75 . The proposed elimination is addressed in article 9 and article 58 of the Bank Indonesia Law. The following will describe four proposals for amendments to that Law. The proposed first 
Table 1. Number of institutions operating in the non-banking financial industry

\begin{tabular}{|c|c|c|c|}
\hline \multirow{2}{*}{ Financial institution } & \multicolumn{2}{|c|}{ September 2020} & \multirow{2}{*}{ Total } \\
\hline & Conventional & Sharia & \\
\hline Insurance & 139 & 13 & 152 \\
\hline Financial institution & 235 & 9 & 244 \\
\hline Pension fund & 216 & 4 & 220 \\
\hline Specialized financial institutions & 112 & 5 & 117 \\
\hline Non-bank financial industry & 228 & 0 & 228 \\
\hline Micro finance institution & 146 & 77 & 223 \\
\hline Fintech & 145 & 11 & 156 \\
\hline TOTAL & 1,221 & 119 & 1,340 \\
\hline
\end{tabular}

amendment is a proposal to return the banking supervision function from the Financial Services Authority to Bank Indonesia. In Indonesia today, The Financial Services Authority performs supervising banking institutions in the macro-prudential field under the Financial Services Authority Law. Bank Indonesia has the task of regulating and supervising banking institutions in the macroprudential sector. Supervision of the micro-prudential Financial Services Authority before the Financial Services Authority's existence was the task and Authority of Bank Indonesia. The transfer of supervisory duties from Bank Indonesia to the Financial Services Authority is based on Article 34 of the Bank Indonesia Law. The Bank Indonesia Law's proposed amendment is to return regulating and supervising banks from the Financial Services Authority to Bank Indonesia, both on micro-prudential and macroprudential matters. The objective of returning the supervisory duties of banking institutions to Bank Indonesia is to make macroeconomic stability more effective. It means that replacing the tasks and supervisory authority of banking institutions with Bank Indonesia will support macroeconomic stability. It is a proposal for changes and improvements in macroeconomic management. The goal is that the Bank Indonesia and the Government synergy will help achieve and maintain economic stability.

The number of financial institutions under the Financial Services Authority can be obtained by integrating the financial institutions' regulation and supervision. The number of banks is 110 commercial banks and 1,517 rural banks, as well as 123 securities companies (FSA, 2021). The number of commercial bank offices is 30,837 , and there are
5,936 rural bank offices throughout Indonesia. The capital market is an institution that is the domain of supervision and regulation of the Financial Services Authority. The data above shows that 123 securities companies are operating in the capital market. However, various other parties/companies are involved in capital market activities under the regulation and supervision of the Financial Services Authority. These companies, among others, include securities administration bureaus, securities rating companies, and trustees. The number of companies is enormous. Many companies operating in the non-bank financial industry under the Financial Services Authority will be presented below.

The data above shows that there are 1,340 financial institutions operating in the non-banking financial industry. In terms of data, the number of supervised financial institutions can be analyzed as the number of responsibilities for these tasks, which may interfere with the implementation of the Financial Services Authority's duties with the available human resources. Not to mention, there are many unlicensed investment cases in public circulation, which will disturb public confidence in financial institutions and the Financial Services Authority itself. There is a limited number of human resources for the provision of financial services. In addition, the debate on the concept of Article 34 is still recorded in the Constitutional Court Decision. It became challenging to agree to this proposal. The process of shifting regulatory and supervisory tasks from Bank Indonesia to the Financial Services Authority requires a lot of time, effort and cost to implement. From the perspective of regulation and supervision of banking in- 
stitutions, there has not been any significant problem that has prompted the Financial Service Authority's duties to Bank Indonesia. The second proposed amendment concerns the position of independence of Bank Indonesia. Proposed changes related to the consequences of changing the meaning of Bank Indonesia independence are contained in the Proposed Amendments to the Bank Indonesia Law, Articles 4 and 7, the abolition of Article 9, items 9A, 9B, 9C, and 10. The proposed amendments to Article 4 emphasize that Bank Indonesia is an independent central bank, but Article 4 adds the phrase "cooperate with the government." This phrase is a proposed amendment to the Bank Indonesia Law. The term disturbs the meaning of Bank Indonesia's independence in the existence of the Bank Indonesia Law. In concept, the measure of a central bank's independence is the central bank authority in determining monetary policy (Moutot, 2020). If the proposal removes the Central Bank's Authority in deciding economic policy, then the request is contrary to its independence concept. Furthermore, the proposal to abolish Article 9 of the Bank Indonesia Law, which stipulates the prohibition of intervening in the implementation of Bank Indonesia's duties, further obscures the meaning of independence in the Law of Bank Indonesia. Suppose a change in the definition of independence is used to justify the Bank Indonesia Law Amendment. It is questionable whether the empirical facts show that Bank Indonesia independence is the root cause of the current economic stability problem. The pandemic is the cause, not because of the independence of Bank Indonesia. This proposed change would hamper the Law's goal of benefiting society, as Jeremy Bentham argued. The third proposed amendment is to replace the formulation of Indonesia's Bank objectives and tasks. Bank Indonesia's current objectives state that Bank Indonesia aims to attain and maintain the rupiah value's stability. Bank Indonesia shall implement monetary policy in a sustainable, consistent and transparent manner and consider the Government's general guidelines in the economic sector. At the same time, Bank Indonesia's objectives can be achieved by carrying out the three tasks of Bank Indonesia as set out in Article 8. To accomplish the Bank Indonesia objectives referred to in Article 7 of the Law, Bank Indonesia has the following tasks: to establish and implement mone- tary policy, regulate and maintain the smooth operation of the payment system, and regulate and supervise banks. The aim of Indonesia's proposed changes to the Bank is only to maintain macroeconomic stability and promote economic growth and the creation of sustainable employment opportunities. Proposed tasks for Bank Indonesia are contained in Article 6. The proposed change in the objectives and tasks of Bank Indonesia follows on from the proposal to return micro-prudential banking duties to Bank Indonesia from the Financial Services Authority. The fourth proposed amendment is to establish a Monetary Board. The existence of the Monetary Board is not currently regulated in Indonesia. The provisions of the Monetary Board existed during the Old Order period. In the Regulatory Period in the Indonesian Old Order, provisions were governing the Monetary Board's existence. This provision has the consequence that the position between the Central Bank and the Government is not firm. This provision had an adverse effect on Bank Indonesia's independence because Bank Indonesia was chaired by a Monetary Board, one of the Ministers of Finance. So it was not legalized in the existing Law of Bank Indonesia. The establishment of a Monetary Board is proposed in accordance with Articles 9A, 9B, and C. Article 9B, paragraph 1, provides for the establishment of a Monetary Board. The Minister of Finance will chair the Monetary Board. Monetary Board members consist of the Minister of Finance, one Minister in charge of the economy, Governor of Bank Indonesia, Senior Deputy Governor of Bank Indonesia, and a Chairman of the Board of Commissioners of the Financial Services Authority. This Council has the function of being able to lead, coordinate, and direct under the authority of Bank Indonesia. The goal is that Bank Indonesia's policies align with general guidelines in the Government's field, the Authority of the Government. The goal is for the Bank Indonesia to have independence to coordinate with the Government in developing policies to maintain economic stability. There is a relationship between the determination of monetary policy and a country's financial stability (Nair \& Anand, 2020). This explanation shows that the experience of the harmful consequences of having a Monetary Board in the Bank Indonesia Act demands the elimination of this institution. This means that if, 
in its development, the Monetary Board's proposal is considered relevant again in the proposed amendments to the Law on Bank Indonesia, the negative impact of the implementation experience in the previous period should be taken into consideration. The establishment of the Monetary Board will disrupt the position of Bank Indonesia's independence. That proposal is irrelevant in solving current banking problems. The common situation with economic stability can be achieved from many perspectives of the related institutions. The associated institutions are Bank Indonesia as a Monetary Authority, the Financial Services Authority as an Authority for all financial institutions in Indonesia, the Deposit Insurance Corporation as a party that guarantees customer deposits, and the government party that organizes economic activities. The Government provides an opinion on the proposed changes. The Government believes that the Government's position on Bank Indonesia's role in maintaining economic stability is that the monetary policy of Bank Indonesia must be credible, effective, and independent (CNBC, 2020). It can be analyzed that the Government has not changed the importance of changing the current Bank Indonesia Law. Addressing efforts are linked to the impact of COVID-19. As it is known, the proposed amendments to laws in Indonesia are proposals from the
House of Representatives. The Government focuses on fighting COVID-19, economic recovery, and maintaining financial system stability. The most important thing for the Government is the division of tasks and responsibilities, the check and balance mechanism of the institutions involved in achieving stability of the financial system. Financial system stability is urgently needed in the situation of the spread of COVID-19 in Indonesia. From a monetary perspective, it is imperative to have good coordination between the Government and Bank Indonesia. When interpreting arguments by analogy (Sudikno Mertokusumo, 2016), any proposed changes should be based on events that may indicate weaknesses in the current Financial Services Authority's supervision and regulation. The proposed amendments to the Bank Indonesia Law are not yet able to demonstrate the legal function as a social engineering tool, since the proposed amendments have not been able to bring changes to Bank Indonesia for the better. It can be said that the proposed amendments to the Bank Indonesia Law also failed to realize the legal objective of providing benefits to the community. The proposed amendments to the Bank Indonesia Law to address the impact of COVID-19 in Indonesia are not yet relevant.

\section{CONCLUSION}

Based on the results and discussion above, it can be concluded that the proposed amendments to the Bank Indonesia Law are in essence the right of the Indonesia People's Representative Council. Indonesia's People's Representative Council asks for alternative solutions to address the impact of the spread of COVID-19 on Indonesia's banks and economy. The Amendment to the Law requires changes to the Bank Indonesia Law. In essence, however, the proposed amendments to the Indonesian Bank Law concerned the return of the banking supervision function from the Financial Services Authority to Bank Indonesia. Changes in the concept of Bank Indonesia independence, changes in the formulation of Bank Indonesia's objectives, and the proposal to establish a Monetary Board are not appropriate until empirical facts prove weaknesses in implementing regulatory and supervisory mechanisms of Financial Services Authority for Banking. The spread of COVID-19 is a situation that has not provided a practical basis that requires amendments to the Bank Indonesia Law as an alternative solution. Therefore, the proposed amendment to the Law of Bank Indonesia is irrelevant in delivering solutions to the impact of COVID-19 in Indonesia. The proposed amendments to the Bank Indonesia Law cannot demonstrate the legal function as a social engineering tool. The proposed amendments to the Bank Indonesia Law have also failed to fulfill the lawful objective of providing benefits to the community, so they are not yet relevant as a solution to the impact of the spread of COVID-19 in Indonesia. A limitation of this study is that it focuses on four proposed changes to the Bank Indonesia Law. There are several proposals for amendments to the Law on Bank Indonesia that can be the subject of further research. 


\section{AUTHOR CONTRIBUTIONS}

Conceptualization: Theresia Anita Christiani.

Data curation: Theresia Anita Christiani.

Formal analysis: Theresia Anita Christiani.

Funding acquisition: Theresia Anita Christiani.

Investigation: Theresia Anita Christiani.

Methodology: Theresia Anita Christiani.

Project administration: Theresia Anita Christiani.

Resources: Theresia Anita Christiani.

Supervision: Theresia Anita Christiani.

Validation: Theresia Anita Christiani.

Visualization: Theresia Anita Christiani.

Writing - original draft: Theresia Anita Christiani.

Writing - reviewing \& editing: Theresia Anita Christiani.

\section{ACKNOWLEDGMENT}

Thanks to Universitas Atma Jaya Yogyakarta, Indonesia, for providing funding for research and publication.

\section{REFERENCES}

1. Aguir, A. (2018). Central Bank Credibility, Independence, and Monetary Policy. Journal of Central Banking Theory and Practice, 3, 91-110. https://doi. org/10.2478/jcbtp-2018-0025

2. Andriani, Y., \& Gai, P. (2013). The Effect of Central Bank Independence on Price Stability: The Case of Indonesia. Buletin Ekonomi Moneter Dan Perbankan, 15(4), 367-390. https://doi. org/10.21098/bemp.v15i4.72

3. Azikin, H. Z. (2015). Pengantar Hukum Perbankan Indonesia. Jakarta: Raja Graffindo Perkasa. Retrieved from http://www.rajagrafindo.co.id/produk/pengantarhukum-perbankan-indonesia/

4. Barry, N. P. (1989). Law and Social Control. In An Introduction to Modern Political Theory (pp. 29-57). Macmillan Education UK. Retrieved from https://link. springer.com/chapter/10.1007\% 2F978-1-349-20201-0_2

5. Barth, J. R., Caprio, G., \& Levine, R. (2004). Bank regulation and supervision: what works best? Journal of Financial Intermediation, 13(2), 205-248. https://doi. org/10.1016/j.jfi.2003.06.002
6. Cello, L. (2021). Jeremy Bentham's vision of international order. Cambridge Review of International Affairs, 34(1), 46-64. https://doi.or g/10.1080/09557571.2020.1722610

7. CNBC. (2020). Simak! Pernyataan Sri Mulyani Soal Amandemen UU BI. Retrieved from https:// www.cnbcindonesia.com/ news/20200904171744-8-184481/ simak-pernyataan-sri-mulyanisoal-amandemen-uu-bi

8. Cottarelli, C. (1994). Should an "Independent" Central Bank Control Foreign Exchange Policy? In T. J. T. Baliño \& C. Cottarelli (Eds.), Frameworks for Monetary Stability (pp. 330-356). International Monetary Fund. https://doi. org/10.5089/9781557754196.071

9. Ekeløve-Slydal, G. (2018). Jeremy Bentham's Legacy: A Vision of an International Law for the Greatest Happiness of All Nations. In M. Bergsmo \& E. J. Buis (Eds.), Philosophical Foundations of International Criminal Law: Correlating Thinkers (pp. 429-485). Brussels: Torkel Opsahl Academic EPublisher. Retrieved from https:// www.legal-tools.org/doc/76b5aa/ pdf/

10. Ferr'e, M., \& Manzano, C. (2020). Independent Central Bank: Low Inflation at No Cost? A Model with Fiscal Policy. International Journal of Central Bank, 16(6), 233-286. Retrieved from https:// www.ijcb.org/journal/ijcb20q5a6. pdf

11. Financial Services Authority (FSA). (2020). Statistic IKNB Periode September 2020. Retrieved from https://www.ojk.go.id/id/ kanal/iknb/data-dan-statistik/ statistik-iknb/Pages/StatistikIKNB-Periode-September-2020. aspx

12. Gaganis, C., Pasiouras, F., \& Wohlschlegel, A. (2021) Allocating supervisory responsibilities to central bankers: Does national culture matter? International Review of Law and Economics, 67, 105991. https://doi. org/10.1016/j.irle.2021.105991

13. Josey, A. (2019). Jeremy Bentham and Canadian Evidence Law: The Utilitarian Perspective on Mistrial Applications. Manitoba Law Journal, 42(4), 291-313. 
Retrieved from https://journals. library.ualberta.ca/themanitobalawjournal/index.php/mlj/article/ view/1132/1119

14. Kroncke, J. J. (2012). Roscoe Pound in China: A Lost Precedent for the Liabilities of American Legal Exceptionalism. Brooklyn Journal of International Law, 38(1), 77-143. Retrieved from https://brooklynworks. brooklaw.edu/cgi/viewcontent. cgi article $=1065 \&$ context $=$ bjil

15. Legislation of the Republic of Indonesia. (1999). Law Number 23 of 1999 Concerning Bank Indonesia. Retrieved from http:// www.flevin.com/id/lgso/translations/Laws/Law\%20No.\%2023\%20 of $\% 201999 \% 20$ on $\% 20$ Bank $\% 20$ Indonesia\%20(BI).pdf

16. Legislation of the Republic of Indonesia. (2004). Law Number 3 of 2004 Concerning Amendments to Law of the Republic of Indonesia Number 23 of 1999.

Retrieved from https://www. bi.go.id/en/tentang-bi/profil/ uu-bi/UndangUndang\%20BI/ Act-Of-The-Republic-Of-Indonesia-Number-3-Of-2004-Concerning-Amendment-To-ActOf-The-Republic-Of-IndonesiaNumber-23-Of-1999-ConcerningBank-Indonesia.pdf

17. Legislation of the Republic of Indonesia. (2009). Law Number 6 of 2009 Concerning Stipulation of Government Regulations in place of Law No. 2 of 2008 Concerning the Second Amendment of Law Number 23 of 1999. Retrieved from https:// www.bi.go.id/en/tentang-bi/ profil/uu-bi/UndangUndang $\% 20$ BI/Act-Of-The-Republic-OfIndonesia-Number-6-Of2009-Concerning-Stipulation-OfGovernment-Regulation-In-LieuOf-Act-Number-2-Of-2008-Concerning-Second-AmendmentTo-The-Act-Number-23-Of1999-Concerning-Bank-Indonesia. pdf

18. Legislation of the Republic of Indonesia. (2011). Law Number 21 of 2011 Concerning the Financial Services Authority. Retrieved from https://www.ojk.go.id/en/ regulasi/otoritas-jasa-keuangan/
undang-undang/Documents/

Pages/Law-of-the-Republic-of-Indonesia-Number-21-of-2011-onFinancial-Services-Authority/ LAW\%20NUMBER\%2021\%20 OF\%202011\%20ON\%20FINANCIAL\%20SERVICES\%20AUTHORITY\%20(OFFICIAL).pdf

19. Legislation of the Republic of Indonesia. (2020a). Government Regulation in Lieu of Law Number 1 of 2020 concerning State Financial Policy and Financial System Stability for Handling the Corona Virus Disease 2019 (COVID-19) Pandemic and/or in Facing Threats That Endanger the National Economy and/ or Financial System Stability. Retrieved from https://peraturan. bpk.go.id/Home/Details/135060/ perpu-no-1-tahun-2020

20. Legislation of the Republic of Indonesia. (2020b). Law No. 2 of 2020 Stipulation of Government Regulation in Lieu of Law No. 1 of 2020 concerning State Financial Policy and Financial System Stability for Handling the Corona Virus Disease 2019 (Covid-19) Pandemic and/or In Facing Threats That Endanger the National Economy and/or Financial System Stability Becomes Law. Retrieved from https://peraturan.bpk.go.id/ Home/Details/137323/uu-no2-tahun-2020

21. Mokriski, D. (2020). The Eligibility of Rule Utilitarianism. Journal of Ethics and Social Philosophy, 17(3), 259-285. https://doi.org/10.26556/ jesp.v17i3.792

22. Moutot, P. (2020). Independence of Central Banks: The Need for an Urgent Revamp! Accounting Economics and Law: A Convivium. https://doi.org/10.1515/ael-20190070

23. Nair, A. R., \& Anand, B. (2020). Monetary policy and financial stability: Should central bank lean against the wind? Central Bank Review, 20(3), 133-142. https://doi. org/10.1016/j.cbrev.2020.03.006

24. Niesen, P. (2019). Speech, Truth and Liberty: Bentham to John Stuart Mill. Journal of Bentham
Studies, 18(1), 1-19. https://doi. org/10.14324/111.2045-757X.046

25. Ozili, P. K. (2020). Does the competence of central bank governors influence financial stability? Future Business Journal, 6(1), 24. https://doi.org/10.1186/ s43093-020-00031-y

26. Riles, A. (2021). The Legitimacy of Central Banking. In Financial Citizenship (pp. 1-8). Cornell University Press. https://doi. org/10.7591/9781501732744-001

27. Stone, J. (1966). Law and Society in the Age of Roscoe Pound: A Memorial. Israel Law Review, 1(1), 173-221. https://doi.org/10.1017/ S002122370001373X

28. Sudiarawan, K., Utami, P. D. Y., Saputra, G. A. A., \& Karunian, A. Y. (2020). Indonesian Labor Sector During Covid-19: Weighing the Impact of Company Saving Policy and Workers Protection. Jurnal Magister Hukum Udayana (Udayana Master Law Journal), 9(4), 684-700. Retrieved from https://ojs.unud.ac.id/index.php/ jmhu/article/view/64927

29. Sudika Mangku, D. (2021). Legal Protection for Women and Children with Disabilities in Indonesia. Jurnal Magister Hukum Udayana (Udayana Master Law Journal), 10(1), 1-14. Retrieved from https://ojs.unud.ac.id/index. $\mathrm{php} / \mathrm{jmhu} /$ article/view/69515

30. Sudikno Mertokusumo, S. H. (2016). Mengenal Hukum. Yogyakarta, Cahaya Atma.

31. Suhartini, E., Hartiwiningsih, Handayani, I. G. A. K. R., \& Roestamy, M. (2019). Legal Politics and Politics Setting of Wage Systems for Creating Social Justice of Workers. Journal of Legal, Ethical and Regulatory Issues, 22(6), 1-7. Retrieved from https:// www.proquest.com/openview/9 0577bc1b9336099a4070d8760e2 $7 \mathrm{ef} 3 / 1$

32. Suradiyanto. (2019). The investment law development to increase investment in Indonesia. International Journal of Law and Management, 61(1), 17-23. https://doi.org/10.1108/IJLMA-11-2017-0270 
33. Szpojankowski, A. O. (2019). Prawo jako narzędzie inżynierii społecznej w filozofii prawa Roscoe Pounda. Archiwum Filozofii Prawa i Filozofii Społecznej, 1, 94-107. https://doi. org/10.36280/AFPiFS.2019.1.94

34. Tholl, J., Schwarzbach, C., Pittalis, S., \& von Mettenheim, H. J. (2020).
Bank funding and the recent political development in Italy: What about redenomination risk? International Review of Law and Economics, 64, 105932. https://doi. org/10.1016/j.irle.2020.105932

35. Wirawan, A., \& Saputra, A. H. (2020). Public Benefit of Economic Consideration of Asset
Management from Corporate Corruption in Indonesia. Journal of Legal, Ethical and Regulatory Issues, 23(5), 1-8. Retrieved from https://www.abacademies. org/articles/Public-benefit-ofeconomic-considerationoof-asset-1544-0044-23-5-520.pdf 